\title{
Prediksi Kebangkrutan Menggunakan Altman Z-Score dan Zmijewski pada PT Prasidha Aneka Niaga Tbk Periode 2014-2018
}

\author{
Bankruptcy prediction using Altman Z-Score and Zmijewski at PT Prasidha Aneka \\ Niaga Tbk 2014-2018 period
}

\section{Widya Saviera Putri}

Program Studi D3 Keuangan dan Perbankan, Politeknik Negeri Bandung

Email: widya.saviera.kepn17@polban.ac.id

\section{Iwan Setiawan}

Jurusan Akuntansi, Politeknik Negeri Bandung

Email: iwan.setiawan@polban.ac.id

\section{Benny Barnas}

Jurusan Akuntansi, Politeknik Negeri Bandung

Email: benny.barnas@polban.ac.id

\begin{abstract}
The growth of the company listed on the IDX is experiencing the highest achievement as the most listed exchange of IPO in the ASE AN region. The fluctuation of the profit generated by PT. Prasidha Aneka Niaga Tbk. which tends to suffer losses in the year of research, the research aims to predict bankruptcy at PT. Prasidha Aneka Niaga Tbk. using the Altman ZScore and Zmijewski method. The method of study that was used is a descriptive method. The data used is based on the annual financial report. The results showed that bankruptcy predictions using the Altman model of the company's Z-Score were in the grey area and had potential bank ruptcy category. While bankruptcy predictions using Zmijewski the company is in a bealthy category. Based on the said calculations, the company has produced different results, but judging from the ratio of each model the company is in position of vigilant bankruptcy.
\end{abstract}

Keywords: bankcrupty, altman z-score, zmijewski

\section{Pendahuluan}

Perkembangan perusahaan yang tercatat di BEI pada tahun 2018 dapat ditandai dengan berhasilnya memfasilitasi 57 perusahaan untuk IPO. Hal tersebut merupakan pencapaian tertinggi sejak 26 tahun terakhir dari privatisasi bursa efek dan bursa yang terbanyak mencatatkan Initial Public Offering di ASEAN dimana Indonesia mencatat 57, Malaysia mencatat 22, Thailand mencatat 19, Singapore mencatat 17, Vietnam mencatat 35, dan Filipina mencatat 1. Pertumbuhan jumlah Perusahaan Tercatat sangat baik dari tahun 2014 sampai April 2019 pertumbuhan jumlah Perusahaan Tercatat di Indonesia mengalami kenaikan hingga 24,3 persen. (Sadono, 2019)

Industri makanan dan minuman merupakan salah satu sektor manufaktur yang memberikan kontribusi besar terhadap pertumbuhan ekonomi nasional. Kinerja industri makanan dan minuman tercatat konsisten memiliki perkembangan yang positif, dalam hal peningkatan produktivitas, investasi, ekspor hingga penyerapan tenaga kerja. Industri makanan dan minuman tahun 2018 mampu tumbuh sebesar 7,91 persen atau melampaui pertumbuhan ekonomi 
nasional yaitu sebesar 5,17 persen. (Kemenperin, 2019)

Di sisi lain, pertumbuhan itu tidak terjadi mer ata di semua perusahaan industri makanan dan minuman. Salah satunya disebabkan oleh pelemahan harga komoditas internasional yang diakibatkan oleh perang dagang Amerika Serikat dan China. Perang dagang kedua negara tersebut memberikan dampak negatif bagi Indonesia. Dimana dampaknya dapat menekan ekspor beberapa barang komoditas unggulan di Indonesia seperti minyak kelapa sawit dan karet.(Bappenas, 2018) Berikut rata-rata harga karet remah berdasarkan harga acuan Singapore Commodity pada tahun 2013 hingga tahun 2018.

Tabel 1. Rata-Rata Harga Karet Remah Berdasarkan Harga Acuan SICOM TSR20 Tahun 2013-2018 (dalam Singapore Dollar).

\begin{tabular}{|c|c|}
\hline Tahun & Rata-Rata Harga Karet Remah \\
\hline 2013 & 246,3 \\
\hline 2014 & 168,8 \\
\hline 2015 & 136,5 \\
\hline 2016 & 139,1 \\
\hline 2017 & 163,5 \\
\hline 2018 & 135,1 \\
\hline
\end{tabular}

Sumber : id.investing.com

Berdasarkan Tabel 1. rata-rata harga komoditas karet remah tahun 2014 mulai mengalami penurunan yang cukup signifikan yang terus terjadi hingga tahun 2016. Tahun 2017 rata-rata harga komoditas karet remah mengalami kenaikan tetapi tidak berlangsung lama tahun 2018 rata-rata harga kembali mengalami penurunan. Pelemahan harga komoditas yang diakibatkan perang dagang Amerika Serikat dan China dapat berisiko pada turunnya kinerja ekspor Indonesia dan defisit perdagangan Indonesia akan terus terjadi (Bappenas, 2018). Dampak dari pelemahan harga komoditas karet remah dirasakan pula oleh perusahaan dalam negeri yang menyebabkan penurunan penjualan komoditas perusahaan, seperti PT. Prasidha Aneka Niaga Tbk. yang mana merupakan objek penelitian penulis. Produksi karet remah merupakan komoditas utama PT. Prasidha Aneka Niaga Tbk. Akan tetapi, pada tahun 2014 perusahaan ini mulai mengalami kerugian yang terjadi secara fluktuatif selama lima tahun sampai 2018. Selain itu, pendapatan neto perusahaan juga mengalami fluktuatif dari tahun 2014 sampai dengan 2018. Dimana pada tahun 2013 perusahaan tidak mengalami kerugian tetapi pada tahun selanjutnya mengalami penurunan pendapatan sekaligus perusahaan mengalami kerugian.

Tabel 2. Pergerakan Total Harta, Total Utang, Total Pendapatan, dan Total Laba / Rugi Usaha pada PT. Prasidha Aneka Niaga Tbk. Periode 2014-2018. (Dalam Rupiah)

\begin{tabular}{|c|c|c|c|c|}
\hline Tahun & Total Harta & Total Utang & Pendapatan Neto & Laba/Rugi Usaha \\
\hline 2014 & Rp 622.508.294.824 & Rp 250.785.019.608 & Rp 975.081.057.089 & Rp (30.238.642.061) \\
\hline 2015 & Rp 620.398.854.182 & Rp 296.079.753.266 & Rp 884.906.826.184 & $\operatorname{Rp}(43.116 .341 .800)$ \\
\hline 2016 & Rp 653.809.571.083 & Rp 373.511.385.025 & Rp 932.905.806.441 & Rp ( 41.068.341.783) \\
\hline 2017 & Rp 691.014.455.523 & Rp 391.494.545.680 & Rp1.399.580.416.996 & Rp $\quad 26.376 .620 .585$ \\
\hline 2018 & Rp 697.657.400.651 & Rp 454.760.270.998 & Rp1.334.070.483.011 & Rp ( 41.264.215.665) \\
\hline
\end{tabular}

Sumber : Data diolah 
Berdasarkan Tabel 2. dapat diketahui bahwa pendapatan mengalami fluktuatif begitu juga dengan laba/rugi usaha yang dihasilkan. Pendapatan pada tahun 2014 mengalami penurunan jika dibandingkan dengan pendapatan pada tahun 2013 yaitu sebesar Rp 1.279.553.071.584 menjadi mengalami penurunan sebesar $23,8 \%$ dan pada tahun 2015 perusahaan juga mengalami penurunan pendapatan sebesar 10,19\%. Namun, pada tahun 2016 dan 2017 perusahaan mengalami kenaikan pendapatan secara berturut-turut yaitu sebesar 5,14\% dan 33,43\%. Sedangkan tahun 2018 perusahaan kembali mengalami penurunan pendapatan sebesar 4,91\%. Selain itu, laba/rugi yang diperoleh perusahaan juga mengalami penurunan pada tahun 2014, 2015, 2016, dan 2018. Perusahaan tahun 2014 mengalami kerugian hingga mencapai penurunan laba sebesar $241,82 \%$ dari tahun 2013 dan mengalami penurunan kerugian pada tahun 2016 sebesar 4,99\%. Pada tahun 2017 perusahaan ini memperoleh laba kembali dari tahun sebelumnya mencapai sebesar $255,7 \%$. Namun, pada tahun 2018 perusahaan mengalami kerugian lagi yang cukup drastis. Sedangkan total aset dan total utang mengalami peningkatan setiap tahunnya karena PT. Prasidha Aneka Niaga Tbk guna membangun pabrik baru untuk meningkatkan produksi kopi olahan yang diharapkan dapat membantu kinerja keuangan perusahaan ditengah melemahnya harga komoditas karet remah dan kopi.

Jika perusahaan mulai menghadapi masalah untuk menciptakan laba maka memungkinkan perusahaan mulai memasuki masa kesulitan keuangan dan apabila kondisi tersebut tidak cepat diatasi maka perusahaan dapat berpotensi untuk mengalami kebangkrutan. Untuk menghindari kebangkrutan dibutuhkan peram pihak internal atau eksternal untuk melakukan berbagai kebijakan, strategi, dan bantuan (Fahmi, 2015)

Prediksi kebangkrutan perusahaan dapat diukur melalui laporan keuangan. Terdapat berbagai alat untuk mendeteksi dan memprediksi potensi mengalami kesulitan keuangan mulai dari kesulitan memiliki likuiditas sampai dengan potensi mengalami kebangkrutan. Salah satunya dengan menggunakan analisa rasio yang dinilai mampu mendeteksi adanya kekuatan dan kelemahan finansial perusahaan. (Setyorini \& Ardiati, 2006)

Formula untuk memprediksi kebangkrutan telah banyak dikembangkan, salah satu model yang banyak digunakan dalam berbagai penelitian dan analisis secara umum yaitu model Altman ZScore. Model Altman Z-Score mempergunakan pendekatan analisis diskriminan (Fahmi, 2015). Perkembangan Model Altman dimulai dari model Altman Z-Score Pertama (1968) yang ditujukan untuk memprediksi kebangkrutan perusahaan publik manufaktur yang sudah go public (Hanafi, 2010). Model Altman Z-Score merupakan model dengan menggunakan Multiple Discriminant Analysis dimana analisis ini menggunakan koefisien yang tepat mengacu pada rasio-rasio keuangan perusahaan dengan menggunakan variabel-variabel dalam modelnya. Selain karena model Altman Pertama ditujukan untuk memprediksi kebangkrutan perusahaan manufaktur yang sudah go public model ini juga melakukan perbandingan rasio penjualan terhadap total aset. Dimana objek penelitian ini mengalami kerugian yang sangat dipengaruhi oleh tingkat penjualan perusahaan. Model Altman lebih menekankan prediksi dalam mengukur profitabilitasnya.

Selain itu, penulis juga menggunakan perhitungan prediksi kebangkrutan Model ZmijewskiXScore. Model Zmijewski memiliki karakteristik berbeda dengan Model Altman dan Grover, dimana model Zmijewski lebih menekankan pada ukuran utang sedangkan kedua model lainnya tersebut lebih menekankan pada ukuran profitabilitas (Gunawan et al., 2017). Selain itu, Model Zmijewski telah menerapkan modelnya pada 40 perusahaan yang telah bangkrut dan 800 perusahaan yang masih bertahan pada saat itu. Rasio yang digunakan dalam Model Zmijewski yaitu rasio Return On Asset, Debt Ratio, dan Current Ratio.

Berdasarkan fenomena diatas maka penulis tertarik untuk melakukan penelitian dengan judul "Prediksi Kebangkrutan dengan Menggunakan Model Altman Z-Score dan Zmijewski pada PT. Prasidha Aneka Niaga Tbk. Periode 2014-2018" 


\section{Kajian Pustaka}

\subsection{Kebangkrutan}

Kebangkrutan merupakan kondisi dimana perusahaan tidak mampu lagi untuk melunasi utangnya. Kondisi ini biasanya memiliki indikasi awal dari perusahaan tersebut dengan melakukan analisis melalui laporan keuangan. Dengan menghitung rasio keuangan dari laporan keuangan perusahaan dapat digunakan sebagai mengindikasi adanya kemungkinan mengalami kebangkrutan di perusahaan (Toto, 2011).

\subsection{Prediksi Kebangkrutan dengan Model Altman Z-Score}

Edward Altman menerapkan Multiple Discriminant Analysis untuk pertama kalinya pada tahunn 1968. Model perhitungan ini dilakukan Altman dengan mengindikasikan rasiorasio keuangan yang memiliki kemungkinan financial distress (Hanafi, 2014). Persamaan diskriminan model Altman Pertama dijelaskan sebagai berikut.

Keterangan:

$$
Z=1,2 X_{1}+1,4 X_{2}+3,3 X_{3}+0,6 X_{4}+1,0 X_{5}
$$

$X_{1}=\frac{\text { Working Capital }}{\text { Total Asset }}$

$X_{2}=\frac{\text { Retained Earnings }}{\text { Total Asset }}$

$X_{3}=\frac{\text { Earning Before Interest and Taxes }}{\text { Total Asset }}$

$X_{4}=\frac{\text { Market Value of Equity }}{\text { Book Value of Debt }}$

$X_{5}=\frac{\text { Sales }}{\text { Total Asset }}$

Klasifikasi perusahaan yang tidak berpotensi mengalami kebangkrutan dan berpotensi mengalami kebangkrutan didasarkan pada nilai Z-score model Altman Pertama yaitu

a. Nilai $Z<1,81$ maka termasuk perusahaan yang berpotensi mengalami kebangkrutan

b. Nilai $1,81<Z<2,99$ maka termasuk grey area (tidak dapat ditentukan apaka perusahaan tidak berpotensi mengalami kebangkrutan ataupun berpotensi mengalami kebangkrutan)

c. Nilai $>2,99$ maka termasuk perusahaan tidak berpotensi mengalami kebangkrutan

\subsection{Prediksi Kebangkrutan dengan Model Zmijewski}

Model prediksi yang dihasilkan oleh Zmijewski tahun 1983 ini merupakan riset selama 20 tahun yang telah diulang. Zmijewski (1984) menggunakan rasio likuiditas, leverage, dan mengukur kinerja perusahaan (Sari \& Yunita, 2019). Model Zmijewski lebih menekankan ukuran utang dengan tiga rasio keuangan yang digunakan untuk menunjukkan perbedaan signifikan antara perusahaan yang tidak berpotensi mengalami kebangkrutan dan berpotensi mengalami kebangkrutan (Gunawan et al., 2017). Persamaan diskriminan model Zmijewski sebagai berikut :

$$
X=-4,3-4,5 X_{1}+5,7 X_{2}-0,004 X_{3}
$$

Keterangan:

$X_{1}=$ Return On Asset (ROA)

$X_{2}=$ Debt Ratio

$X_{3}=$ Current Ratio (CR)

Klasifikasi perusahaan yang tidak berpotensi mengalami kebangkrutan dan berpotensi mengalami kebangkrutan didasarkan pada nilai Z-score model Altman Pertama yaitu 
a. Nilai X-Score $<0$ maka perusahaan termasuk berpotensi mengalami kebangkrutan

b. Nilai X-Score $>0$ maka perusahaan termasuk tidak berpotensi mengalami kebangkrutan

\subsection{Penelitian Terdahulu}

Kebangkrutan merupakan dampak terburuk dari permasalahan manajemen perusahaan dimana perlu dilakukan pengindikasian sejak awal. Penelitian mengenai model Altman Z-Score dengan Zmijewski dalam memprediksi kebangkrutan pada studi kasus PT. Tiga Pilar Sejahtera Tbk.. Teknik analisis data yang digunakan yaitu melalui perhitungan model Altman Z-Score dan Zmijewski terhadap PT. Tiga Pilar Sejahtera Tbk.. Hasil penelitian menyatakan bahwa Altman Z-Score memprediksi AISA berada pada kategori berpotensi mengalami kebangkrutan pada periode 2015-2017 dan perhitungan Zmijewski memprediksi AISA dalam keadaan yang sehat. Hal ini menunjukkan terdapat perbedaan hasil perhitungan antara Altman Z-Score dengan Zmijewski. Perusahaan perlu melakukan evaluasi agar perusahaan memperbaiki kinerjanya. (Dahni, 2019)

Penelitian mengenai perbandingan prediksi financial distress dengan model Altman, Grover, dan Zmijewski. Teknik sampling menggunakan purposive sampling, dengan populasi berasal dari 151 perusahaan manufaktur yang terdaftar di Bursa Efek Indonesia dengan sampel yang digunakan yaitu 110 perusahaan. Model analisis yang digunakan adalah regresi linear berganda. Hasil penelitian menyatakan bahwa tingkat ketepatan model prediksi kebangkrutan pada perusahaan manufakur tertinggi hingga terendah yaitu model Zmijewski, Grover, dan Altman. Model Zmijewski memiliki tingkat ketepatan yang paling tinggi didasarkan pada uji koefisien determinasi karena nilai nagelkerke $\mathrm{R}$ square memiliki nilai tertinggi diantara tiga model yang diuji. Terdapat perbedaan rasio yang digunakan model Altman dan Grover dengan model Zmijewski. Model Altman dan model Grover menekankan ukuran profitabilitas. Sedangkan model Zmijewski lebih menekankan pada ukuran utang. (Gunawan et al., 2017)

Penelitian mengenai komparasi prediksi kebangkrutan dengan model Ohlson, Springate, Zmijewski dan Grover pernah dilakukan. Populasi yang digunakan adalah 9 perusahaan konstruksi dan bangunan yang terdaftar di BEI dengan sampel 5 perusahaan. Teknik analisis data menggunakan uji beda atau paired sample test dan melakukan perhitungan prediksi kebangkrutan yang memiliki tingkat akurasi yang paling tinggi. Hasil penelitian menunjukkan bahwa model Springate memiliki perbedaan dengan model Zmijewski dan Grover. Sedangkan model Zmijewski memiliki perbedaan dengan model Grover. Model Springate, Zmijewski,dan Grover memiliki tingkat akurasi sebesar 100\%. Sedangkan model Ohlson memiliki tingkat akurasi sebesar 80\%. Hal ini menunjukkan bahwa model Ohlson, Springate, Zmijewski, dan Grover memiliki perbedaan hasil perhitungan satu sama lain dan model perhitungan yang tepat dan akurat untuk perusahaan konstruksi dan bangunan yaitu model Springate, Zmijewski, dan Grover. (Rachaprima et al., 2015)

\section{Metode Penelitian}

Model penelitian yang digunakan adalah penelitian deskriptif dengan pendekatn kuantitatif.

\subsection{Jenis dan Sumber Data}

Dalam penelitian ini bentuk data yang digunakan adalah data kuantitatif. Dilihat dari sumber datanya, dalam penelitian ini jenis data yang digunakan adalah data sekunder dan time series. Data yang digunakan yaitu laporan keuangan PT. Prasidha Aneka Niaga Tbk. Periode 2014 hingga 2018. Sumber data yang digunakan berasal dari laporan keuangan, yang mana data tersebut diperoleh dari website resmi perusahaan yaitu www.prasidha.co.id dan data harga saham PT. Prasidha Aneka Niaga diperoleh dari www.id.investing.com .

\subsection{Teknik Pengumpulan Data}

Teknik pengumpulan data yang digunakan dalam penelitian ini adalah model 
dokumentasi berupa data sekunder melalui laporan keuangan pada PT. Prasidha Aneka Niaga tahun 2014-2018 dan data harga saham PT. Prasidha Aneka Niaga. Selain itu, pengumpulan data menggunakan model studi kepustakaan dengan cara mengumpulkan dan mempelajari buku, artikel, serta literatur lain dan karya tulis ilmiah yang relevan dengan penelitian ini.

\subsection{Teknik Analisis Data}

Data-data yang dianalisis berupa laporan keuangan yang terdiri dari neraca, laporan laba rugi dan data harga saham selama lima periode yaitu 2014, 2015, 2016, 2017, dan 2018. Data tersebut merupakan data mentah sehingga memerlukan pengolahan lebih lanjut.

Dalam menganalisis prediksi kebangkrutan dengan menggunakan teknik analisis datanya sebagai berikut:

1. Menghitung dan menganalisis rasio-rasio keuangan tiap tahunnya dengan menggunakan variabel-variabel yang digunakan dalam model Altman Z-Score Pertama, diantaranya yaitu:
a. Perhitungan $X_{1}=\frac{\text { Working Capital }}{\text { Total Asset }}$
b. Perhitungan $X_{2}=\frac{\text { Retained Earnings }}{\text { Total Asset }}$

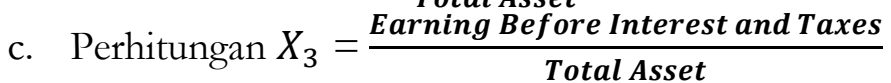
d. Perhitungan $X_{4}=\frac{\text { Market Value of Equity }}{\text { Book Value of Debt }}$
e. Perhitungan $X_{5}=\frac{\text { Sales }}{\text { Total Asset }}$

2. Menghitung nilai Altman Z-Score berdasarkan perhitungan matematika dengan menggunakan diskriminan sebagai berikut:

$$
\mathrm{Z}=1,2 X_{1}+1,4 X_{2}+3,3 X_{3}+0,6 X_{4}+1,0 X_{5}
$$

3. Mengklasifikasikan kondisi perusahaan sesuai dengan hasil perhitungan diatas dengan titik cut-off yang telah ditentukan yaitu:

a. Nilai Z-Score $<1,81$ maka termasuk perusahaan yang berpotensi mengalami kebangkrutan

b. Nilai 1,81 < Z-Score $<2,99$ maka termasuk grey area (tidak dapat ditentukan apaka perusahaan tidak berpotensi mengalami kebangkrutan ataupun berpotensi mengalami kebangkrutan)

c. Nilai Z-Score $>2,99$ maka termasuk perusahaan tidak berpotensi mengalami kebangkrutan

4. Mengambil kesimpulan mengenai prediksi kebangkrutan dari hasil analisis data tersebut.

Selanjutnya, teknik analisis data dengan menggunakan model Zmijewski sebagai berikut:

1. Menghitung dan menganalisis rasio-rasio keuangan tiap tahunnya dengan menggunakan variabel-variabel yang digunakan dalam model Zmijewski, diantaranya yaitu:

a. Perhitungan $X_{1}=$ Return On Asset $=\frac{\boldsymbol{E A T}}{\text { Total Asset }}$

b. Perhitungan $X_{2}=$ Debt Ratio $=\frac{\text { Total Liabilities }}{\text { Total Asset }}$

c. Perhitungan $X_{3}=$ Current Ratio $=\frac{\text { Current Asset }}{\text { Current Liabilities }}$

2. Menghitung nilai Zmijewski berdasarkan perhitungan matematika dengan menggunakan diskriminan sebagai berikut:

$$
\mathrm{X}=-4,3-4,5 X_{1}+5,7 X_{2}-0,004 X_{3}
$$

3. Mengklasifikasikan kondisi perusahaan sesuai dengan hasil perhitungan diatas dengan titik cut-off yang telah ditentukan yaitu:

a. Nilai X-Score $<0$ maka perusahaan termasuk berpotensi mengalami kebangkrutan 
b. Nilai X-Score $>0$ maka perusahaan termasuk tidak berpotensi mengalami kebangkrutan

4. Mengambil kesimpulan mengenai prediksi kebangkrutan dari hasil analisis data tersebut.

\section{Hasil dan Pembahasan}

\subsection{Perhitungan dengan Model Altman Z-Score}

Dalam penelitian ini menggunakan dua model prediksi kebangkrutan. Berikut prediksi kebangkrutan pada PT. Prasidha Aneka Niaga Tbk. Periode Tahun 2014 hingga 2018 menggunakan model Altman Z-Score.

Tabel 3. Perhitungan Altman Z-Score pada PT. Prasidha Aneka Niaga Tbk. Tahun 2014-2018

\begin{tabular}{|c|c|c|c|c|c|c|}
\hline Tahun & $\mathbf{1 , 2 \boldsymbol { X } _ { \mathbf { 1 } }}$ & $\mathbf{1 , 4 \boldsymbol { X } _ { \mathbf { 2 } }}$ & $\mathbf{3 , 3 \boldsymbol { X } _ { \mathbf { 3 } }}$ & $\mathbf{0 , 6 \boldsymbol { X } _ { \mathbf { 4 } }}$ & $\mathbf{1 , 0 \boldsymbol { X } _ { \mathbf { 5 } }}$ & $\mathbf{Z}$-Score \\
\hline 2014 & 0,147 & $-0,017$ & $-0,012$ & 0,821 & 1,566 & 2,170 \\
\hline 2015 & 0,041 & $-0,093$ & $-0,032$ & 0,593 & 1,426 & 1,594 \\
\hline 2016 & 0,030 & $-0,160$ & 0,006 & 0,517 & 1,427 & 1,568 \\
\hline 2017 & 0,077 & $-0,121$ & 0,102 & 0,942 & 2,025 & 2,848 \\
\hline 2018 & 0,012 & $-0,209$ & $-0,004$ & 0,608 & 1,912 & 1,983 \\
\hline
\end{tabular}

Sumber: Data diolah

Berdasarkan Tabel.3 menunjukkan bahwa nilai Z-Score berada kurang dari 2,99 berarti perusahaan berada pada kategori grey area atau berpotensi mengalami kebangkrutan. Tahun 2014 nilai Z-Score PT. Prasidha Aneka Niaga Tbk. berada pada kategori grey area. Kinerja perusahaan tahun 2014 cukup mengkhawatirkan karena memiliki dua rasio dalam model Altman Z-Score yang bernilai negatif yaitu pada rasio Retained Earnings To Total Asset dan Earnings Before Interest and Tax to Total Asset. . Tahun 2015 nilai Z-Score berada kurang dari 1,81, maka PT. Prasidha Aneka Niaga Tbk. berada pada kategori berpotensi mengalami kebangkrutan. Hal ini terjadi karena kelima rasio dalam Altman Z-Score mengalami penurunan dari tahun sebelumnya. Perusahaan tahun 2016 memiliki nilai Z-Score terendah dari periode penelitian ini yaitu sebesar 1,568 dimana PT. Prasidha Aneka Niaga Tbk. berada pada kategori berpotensi mengalami kebangkrutan. Rasio Working Capital to Total Asset, Retained Earning to Total Asset, dan EBIT to Total Asset mengalami penurunan dari tahun 2015. Tahun 2017 nilai Z-Score mengalami kenaikan yang cukup drastis yaitu sebesar 2,848 dimana perusahaan dalam kategori grey area. Namun, nilai Z-Score tahun 2017 hampir mendekati batas titik cut-off ke kategori tidak berpotensi mengalami kebangkrutan. Kinerja perusahaan semakin baik pada tahun 2017 dapat dilihat kelima rasio mengalami kenaikan dari tahun sebelumnya. Tahun 2018 perusahaan memiliki nilai Z-Score sebesar 1,983 dimana kinerja perusahaan mengalami penurunan kembali dari tahun 2017. Nilai Z-Score tahun 2018 dipengaruhi oleh kelima rasio mengalami penurunan dari tahun sebelumnya.

\subsection{Perhitungan dengan Model Zmijewski}

Berdasarkan perhitungan model Zmijewski prediksi kebangkrutan PT. Prasidha Aneka Niaga sebagai berikut.

Tabel 4. Perhitungan Zmijewski pada PT. Prasidha Aneka Niaga Tbk. Tahun 2014-2018

\begin{tabular}{|c|c|c|c|c|}
\hline Tahun & $\mathbf{- 4 , 5 \boldsymbol { X } _ { \mathbf { 1 } }}$ & $\mathbf{5 , 7} \boldsymbol{X}_{\mathbf{2}}$ & $\mathbf{- 0 , 0 0 4 \boldsymbol { X } _ { \mathbf { 3 } }}$ & $\mathbf{X}$-Score \\
\hline 2014 & $-0,049$ & 0,403 & 1,464 & $-1,788$ \\
\hline
\end{tabular}




\begin{tabular}{|c|c|c|c|c|}
\hline Tahun & $\mathbf{- 4 , 5} \boldsymbol{X}_{\mathbf{1}}$ & $\mathbf{5 , 7} \boldsymbol{X}_{\mathbf{2}}$ & $\mathbf{- 0 , 0 0 4 \boldsymbol { X } _ { \mathbf { 3 } }}$ & $\mathbf{X}$-Score \\
\hline 2015 & $-0,069$ & 0,477 & 1,097 & $-1,275$ \\
\hline 2016 & $-0,056$ & 0,571 & 1,060 & $-0,798$ \\
\hline 2017 & 0,047 & 0,567 & 1,159 & $-1,284$ \\
\hline 2018 & $-0,067$ & 0,652 & 1,022 & $-0,286$ \\
\hline
\end{tabular}

Sumber: Data diolah

Berdasarkan Tabel 4. dapat dilihat bahwa nilai X-Score tahun 2014 hingga 2018 berada kurang dari nilai 0 hal ini menunjukkan bahwa perusahaan tidak berpotensi mengalami kebangkrutan atau perusahaan dalam keadaan sehat. Akan tetapi, selama tahun 2014, 2015, 2016, dan 2018 perusahaan memiliki nilai rasio Return On Asset memiliki nilai yang negatif. Nilai Debt Ratio relatif mengalami kenaikan setiap tahunnya yang menunjukkan bahwa perusahaan semakin tinggi menggunakan utang untuk membiayai aset perusahaan. Selain itu juga nilai Current Ratio relatif mengalami penurunan setiap tahunnya walaupun perusahaan masih likuid karena memiliki kemampuan untuk melunasi kewajiban jangka pendek.

Berdasarkan perhitungan model Altman tahun 2015 dan 2016 perusahaan berada dalam kategori berpotensi mengalami kebangkrutan sedangkan model Zmijewski menyatakan perusahaan dalam kategori tidak berpotensi mengalami kebangkrutan. Dapat dilihat dari rasio-rasio yang digunakan dalam kedua model tersebut bahwa tahun 2015 tingkat profitabilitas perusahaan tidak dalam keadaan yang baik dapat dilihat melalui rasio Retained Earnings to Total Asset, EBIT to Total Asset, dan Return On Asset memiliki nilai yang negatif. Akan tetapi, perusahaan masih memiliki tingkat solvabilitas yang cukup baik dilihat dari rasio Market Value of Equity to Book Value of Debt dan Debt Ratio yang memiliki nilai yang positif dan perusahaan masih memiliki aset dan modal sendiri untuk menanggung utang dan tingkat utang perusahaan masih cukup terkendali. Selain itu, perusahaan masih memiliki tingkat likuiditas yang baik dapat dilihat dari rasio Working Capital to Total Asset dan Current Ratio memiliki nilai yang positif yang menunjukkan bahwa perusahaan dapat memenuhi kewajiban jangka pendeknya.

Tahun 2016 mengalami perbedaan dalam hasil perhitungan kedua model. Model Altman memprediksi perusahaan dalam kategori berpotensi mengalami kebangkrutan sedangkan model Zmijewski memprediksi perusahaan dalam kategori tidak berpotensi mengalami kebangkrutan. Dapat dilihat dari rasio-rasio kedua model tersebut bahwa tahun 2016 perusahaan mengalami penurunan kinerja karena dapat dilihat bahwa tingkat solvabilitas perusahaan melalui rasio Market $V$ alue of Equity to Book $V$ alue of Debt dan Debt Ratio yang memiliki nilai yang melemah hal ini menunjukkan perusahaan menjadi kurang sovable dari tahun sebelumnya. Selain itu, tingkat likuiditas perusahaan dilihat dari rasio Current Ratio dan Working Capital to Total Asset perusahaan juga menurun dari tahun sebelumnya tetapi perusahaan tetap dapat memenuhi kewajiban jangka pendeknya. Sedangkan tingkat profitabilitas perusahaan memiliki nilai yang berbeda antara kedua model dimana menurut model Altman tingkat profitabilitas yang diukur dari rasio EBIT to Total Asset memiliki nilai yang cukup baik karena perusahaan dapat menghasilkan laba operasi dari aset yang dimiliki tetapi menurut model Zmijewski tingkat profitabilitas perusahaan yang diukur dari Return On Asset memiliki nilai yang negatif dan mengalami penurunan dari tahun sebelumnya menunjukkan bahwa aset yang dimiliki perusahaan tidak dapat menghasilkan laba setelah pajak. Dari kedua rasio tersebut dapat dilihat bahwa perusahaan dapat menghasilkan laba hanya dapat memenuhi beban-beban operasi perusahaan saja, tidak dapat memenuhi beban bunga dan pajak yang dimiliki perusahaan. 


\section{Penutup}

\subsection{Kesimpulan}

Berdasarkan hasil penelitian mengenai prediksi kebangkrutan dengan model Altman ZScore dan Zmijewski pada PT. Prasidha Aneka Niaga Tbk. Periode 2014-2018, maka penulis dapat menarik kesimpulan bahwa hasil prediksi kebangkrutan menggunakan model Altman Z-Score pada PT. Prasidha Aneka Niaga Tbk. tahun 2014 hingga tahun 2018 secara berturut-turut adalah 2.173, $1.594,1.541,2.850$, dan 1.987. Perusahaan mengalami hasil perhitungan yang berfluktuatif. Tahun 2014, 2017, dan 2018 perusahaan berada pada kategori grey area atau abu-abu. Sedangkan tahun 2015 dan 2016 perusahaan berada pada kategori berpotensi mengalami kebangkrutan.

Hasil perhitungan menggunakan model Zmijewski pada PT. Prasidha Aneka Niaga Tbk. tahun 2014 hingga tahun 2014 hingga 2018 secara berturut-turut adalah -1.791,-1.275, -0.796, 1.285, dan -0.288. Hasil perhitungan dengan menggunakan model Zmijewski berada pada nilai kurang dari nilai 0 hal ini menunjukkan bahwa perusahaan tidak berpotensi mengalami kebangkrutan.

Kondisi keuangan PT. Prasidha Aneka Niaga Tbk. berdasarkan hasil perhitungan prediksi kebangkrutan dengan menggunakan model Altman Z-Score dan Zmijewski, PT. Prasidha Aneka Niaga Tbk. memiliki kesimpulan yang berbeda, tetapi hasil rasio-rasio kedua model tersebut masih memiliki nilai yang negatif disebabkan oleh selama empat periode penelitian perusahaan terus menerus mengalami kerugian. Hasil perhitungan Altman perusahaan dalam posisi berpotensi mengalami kebangkrutan sedangkan menurut model Zmijewski perusahaan dalam posisi sehat. Walaupun hasil perhitungan model Zmijewski berada tidak berpotensi mengalami kebangkrutan tetapi jika dilihat dari nilai perhitungannya, nilai yang dihasilkan tidak jauh lebih kecil dari nilai 0 menunjukkan rasio-rasio yang dihasilkan perusahaan kurang baik sehingga perusahaan mendekati berpotensi mengalami kebangkrutan.

\subsection{Saran}

Dari kondisi yang sudah diuraikan diatas, penelitian ini tidak menggambarkan kondisi perusahaan sebenarnya tetapi dapat dijadikan saran untuk evaluasi kedepannya untuk memperbaiki kinerja perusahaan dapat dilihat beberapa rasio dalam perhitungan prediksi kebangkrutan tersebut memiliki nilai yang negatif. Rasio yang bernilai negatif yaitu rasio yang berhubungan dengan laba perusahaan dan rasio utang juga semakin meningkat tiap tahunnya. Maka perusahaan harus memperbaiki dan mengembangkan usaha atau produk perusahaan secara optimal untuk mengatasi pengaruh dari pelemahan harga komoditas karet remah dan kopi dengan mengelola aset yang dimiliki perusahaan secara optimal dan efisien, mengeluarkan biaya-biaya operasional dan nonoperasional secara efektif, dan tetap memperhatikan tingkat pengembalian kredit kepada debitur.

Bagi peneliti selanjutnya diharapkan dapat melakukan penelitian mengenai prediksi kebangkrutan dengan menambahkan model lain sehingga dapat menghasilkan hasil yang lebih akurat dan waktu penelitian bisa dilakukan lebih dari 5 tahun.

\section{Daftar Pustaka}

Bappenas. (2018). Perkembangan Harga Komoditas Internasional Bulan Juni 2018. Bappenas.Go.Id. https://www.bappenas.go.id/id/profil-bappenas/unit-kerja/deputi-bidangekonomi/direktorat-perencanaan-makro/contents-direktorat-perencanaanmakro/perkembangan-harga-komoditas-di-pasar-internasional/

Dahni, F. (2019). Altman Z-Score Vs Zmijewski X-Score Dalam Memprediksi Kebangkrutan Perusahaan (Studi Kasus PT Tiga Pilar Sejahtera (AISA) Tahun 2015-2017). Jurnal Administrasi Bisnis, 8(2), 65. https://doi.org/10.14710/jab.v8i2.25433 
Gunawan, B., Pamungkas, R., \& Susilawati, D. (2017). Perbandingan Prediksi Financial Distress Menggunakan Model Altman, Grover dan Zmijewski. Jurnal Akuntansi Dan Investasi, 18(1), 119-127. https://doi.org/10.18196/jai.18164

Irham Fahmi. (2015). Analisis Laporan Kenangan. Alfabeta.

Kemenperin. (2019). Industri Makanan dan Minuman Jadi Sektor Kampiun. Kemenperin.Go.Id. https://kemenperin.go.id/artikel/20298/Industri-Makanan-dan-Minuman-Jadi-SektorKampiun-

Mamduh Hanafi. (2010). Manajemen Kenangan (Edisi 1). BPFE.

Mamduh Hanafi. (2014). Manajemen Keuangan Cetakan Ke-7. BPFE.

Prihadi Toto. (2011). Analisa Laporan Keuangan Teori dan Aplikasi. Penerbit PPM.

Rachaprima, M., Idrus, R., \& Tanjung, A. (2015). Analisis Komparatif Prediksi Kebangkrutan Dengan model Ohlson, Springate, Zmijewski, dan Grover pada Perusahaan Konstruksi dan Bangunan yang Terdaftar di Bursa Efek Indonesia. Jurnal Online Mahasiswa Fakultas Ekonomi Universitas Riau, 2(2), 33970.

Sari, M. P., \& Yunita, I. (2019). Analisis Prediksi Kenbangkrutan Dan Tingkat Akurasi Model Springate, Zmijewski, Dan Grover Pada Perusahaan Sub Sektor Logam Dan Mineral Lainnya Yang Terdaftar Di Bursa Efek Indonesia Tahun 2012-2016. Jurnal Imiah Manajemen, 7(1), 69_ 77. https://doi.org/https://doi.org/10.33884/jimupb.v7i1.907

Setyorini, T. N., \& Ardiati, A. Y. (2006). Pengaruh Potensi Kebangkrutan Perusahaan Publik terhadap Pergantian Auditor. Kinerja Journal of Business and Economics, 10(1), 76-87.

Yulianto Aji Sadono. (2019). BEI Optimis Pasar Modal Indonesia Tetap Tumbub Positif. Idx.Co.Id. https:/ / www.idx.co.id/berita/press-release-detail/?emitenCode $=1098$ 